\section{Perceptions of information literacy competencies among future psychology professionals:
a comparative study in Spain and Portugal}

Perceptions of information literacy competencies

\author{
María Pinto
}

Faculty of Information Science, University of Granada, Granada, Spain

Rosaura Fernández-Pascual

Faculty of Economic and Business Sciences, University of Granada, Granada, Spain

Carlos Lopes

ISPA - Instituto Universitário, Lisboa, Portugal and

APPsyCI-Applied Psychology Research Center Capabilities and Inclusion, Lisboa, Portugal

Maria Luz Antunes

ESTeSL (Instituto Politécnico de Lisboa), Lisboa, Portugal and

APPsyCI-Applied Psychology Research Center Capabilities and Inclusion, Lisboa, Portugal, and

Tatiana Sanches

UIDEF, Instituto da Educação, Universidade de Lisboa, Lisboa, Portugal and

APPsyCI-Applied Psychology Research Center Capabilities and Inclusion,

$$
\text { Lisboa, Portugal }
$$

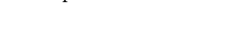

\begin{abstract}
Purpose - The aim of the study is to analyze the perceptions of belief-in-importance (BI), self-efficacy (SE) and preferred source of learning (SL) of information literacy (IL) competencies among psychology students in Spain and Portugal.

Design/methodology/approach - Unified protocol was based on the questionnaire IL-HUMASS (26 items). Quantitative diagnostic-comparative study was carried out, including factor and variance analysis. Hypothesis compliance was checked.

Findings - By country, there are no significant differences in students' perceptions, although the scores in BI are higher than in SE. By category, there are some significant differences, and the least valued is that of processing. By individual competency, seven of them show differences between countries. Learning preferences are for a mix of classroom and autonomous learning. Students barely realize the value of libraries.
\end{abstract}

(C) María Pinto, Rosaura Fernández-Pascual, Carlos Lopes, Maria Luz Antunes and Tatiana Sanches. Published by Emerald Publishing Limited. This article is published under the Creative Commons Attribution (CCBY 4.0) licence. Anyone may reproduce, distribute, translate and create derivative works of this article (for both commercial and non-commercial purposes), subject to full attribution to the original publication and authors. The full terms of this licence may be seen at http://creativecommons. org/licences/by/4.0/legalcode

The authors are deeply grateful to participating students and teaching faculty who have collaborated in the process. Thanks also to Diana Buck, a doctor in education, for her editing work. 
AJIM

73,3

346

Within factor structures, which share the same components in each dimension, some emerging factors do appear.

Practical implications - Motivation (BI and SE) with respect to IL competencies is a key asset for future psychologists. Interest should focus on some emerging motivational factors. Students' appreciation of the library should enhance through the corresponding initiatives for improvement. This method could be complemented by qualitative studies.

Originality/value - This is probably the first diagnostic-comparative study on perceptions of IL competencies among future psychology professionals.

Keywords Information literacy, Competencies, Belief-in-importance, Self-efficacy, Learning source, Higher education, Teaching-learning, Graduate psychology curriculum, Comparative studies

Paper type Research paper

\section{Introduction}

Over the past few years, the increase in available information and its complexity seems unstoppable. This is due largely to the massive incorporation of new information and communication technologies (ICT) into our information society. Therefore, it is easily understandable that the mastery of information literacy (IL) competencies has become a priority issue, especially in higher education (HE) settings. Psychology, as the discipline addressing behavior and mental processes, explores some basic concepts, perceptions, attention, motivation, emotions, thought and communication that are key from the IL perspective. It could be said that IL is nourished, in part, by psychology. But the opposite could also be affirmed, that psychology is supported by some postulates - searching, evaluation, processing, and communication - that are characteristic of IL. In any case, the thematic convergence of both domains has not been sufficiently addressed in the literature. On the other hand, the relationship of students to information is eminently disciplinary. Each discipline has its informational habits. For these reasons, we think that the domain of IL competencies deserves more attention in psychology studies.

Professional organizations related to psychology have called for greater emphasis on IL competencies. This is evidenced by the American Psychological Association's (APA) guidelines for the undergraduate psychology major (APA, 2013, 2016), the Quality Assurance Agency for Higher Education's (QAA) Subject Benchmark Statement in Psychology (QAA, 2016) and the Association of College and Research Libraries' (ACRL) Psychology Information Literacy Standards (ACRL, 2010). This last norm is a clear illustration of the aforementioned convergence since it explicitly relates the discipline of psychology and the subject of IL. Each of these professional organizations identifies comparable learning benchmarks for psychology graduate programs. According to the Tuning project recommendations (Eurydice, 2005), students, regardless of the course, should attain a series of basic competencies, which will later prove essential in their professional lives. These basic abilities will enable them to access, process, evaluate and communicate relevant information from pertinent sources in their area of expertise (Lopes and Pinto, 2013, 2016).

Spain and Portugal are two countries that comprise a unique geographical area, the Iberian Peninsula. Although their similarities in some historical, cultural and linguistic aspects are evident, so are their differences. In general, the knowledge derived from this investigation will permit some joint curricular initiatives, given the growing movement of Erasmus students in both directions. Based on common key values within the European Higher Education Area (EHEA), degrees in psychology were structured according to international criteria, such as that of the European psychology diploma project.

We explored a little-known issue that relates to perceptions of IL competencies among psychology students from both countries. This diagnostic-comparative study addresses perceptions as well as similarities and differences surrounding a series of informational competencies, including those related to the use of ICT. Through this process, we discovered the motivations of these students for integrating technology. 
This case study, involving six groups of future psychologists, aims for a better understanding of their perceptions of a series of basic IL competencies. Data are grounded on three subjective approaches related to their belief-in-importance (BI), self-efficacy (SE) and preferred source of learning (SL). Based on both literature review and research hypotheses, findings provide some diagnosis-comparison on IL competency status among psychology students in the two countries. Finally, some issues in need of assistance are suggested.

\section{Literature review}

As in other areas, $\mathbb{I L}$ has experienced significant changes since the beginning of the new millennium, owing, to a great extent, to the incorporation of ICT technologies to the world of information. This is the case to the extreme that associations in charge of promoting the development of $\mathrm{IL}$ have been obliged to take a serious second look at the fundamentals of the discipline. The standards at the beginning of the century (SCONUL, 1999; ACRL, 2000) were based on a series of competencies in which all students in higher education (HE) should be proficient. However, recent interpretations of $\mathrm{IL}$ as a conceptual framework-among others (SCONUL, 2011; ACRL, 2016; CILIP Information Literacy Group, 2018) address it from a more open, dynamic and contextual perspective. The two approaches are complementary and, as such, should be taken into consideration. We are aware that $\mathrm{IL}$ is not just a condition that students should acquire through a series of competencies. It is also an activity involving critical thinking in a specific context: "IL is not a standard part of classroom content, but appears to be provided only to those students who actively seek out the information" (Schmidt-Hanbidge et al., 2018, p. 132). In this same line, Farkas (2012, pp. 89-90) refers to the necessity of significant changes in the conceptualization of IL: "as ideas about authority and knowledge have changed, so should notions about information literacy." It is likewise necessary for there to be a change in the mentality of the students, who should be more critical: "students will need to be self-directed and critical information seekers, which requires a particular mindset in addition to specific skills."

Like many others, the domain of IL evolves significantly in line with the socio-technological progress of recent years. Limberg et al. (2008, p. 84) are aware of the "tension between a conventional teaching skills-focused approach and the realization of the complex nature of information literacy." They suggest "a view of information literacy as a social practice shaped by the culture and context in which it is embedded." In this sense, rather than IL competencies, there is a need to focus on the culture (psychology) and the context (HE) in which they develop. In summary, IL should be contextualized within the structures and modes of thought of particular disciplines (Grafstein, 2002; Tuominen et al., 2005). Notwithstanding what has been said previously, this literature review only covers the domain of IL competencies from the discipline of psychology.

From a psychological perspective, the International Declaration of Core Competences in Professional Psychology conceives competency as a "combination of practical and theoretical knowledge, cognitive skills, behavior, and values used to perform a specific behavior or set of behaviors to a standard, in professional practice settings associated with a professional role" (IAAP and UPsyS, 2016, p. 4). In this referential document, a set of internationally endorsed competencies for professional psychology are stated. The American Psychological Association (APA, 2002) included a number of competencies in specific knowledge and appropriate attitudes for professional practice. Over the years, some authors have focused on the competencies of psychologists. The seminal article by Kaslow (2004) outlines what later became research lines in this area: the foundational, core and specialty competencies within professional psychology. They were basically concerned with the essential domains, instruction and assessment. These essential domains, also known as the Big 8, refer to ethical and legal issues, individual and cultural diversity, scientific foundations and research, psychological assessment, intervention, consultation and inter-professional collaboration, supervision and professional development.

\section{Perceptions of information literacy competencies}


AJIM

73,3

348
From an HE context, the degree in psychology in Spain entails a master's level qualification, following a four-year sequence. In this same line, programs in Portugal are organized into master's level with two study cycles, the first lasting three years (bachelors-equivalent) and the second for two years (a master's degree). In both countries, the first phase is believed to introduce the most important theories and methods of the discipline (primary competencies). The second phase enables specialized competencies. Both primary and empowering competencies are essential (EuroPsy, 2011).

Yet beyond academic training based on domain competencies, a set of IL competencies is also required. The goal should be achieving specific equivalent IL benchmarks to psychologyrelated standards. From a pedagogical perspective, Birkett and Hughes (2013) pursue a number of objectives: (1) address the complementary IL standards through collaborative instruction, (2) assign projects for students to practice and demonstrate mastery and (3) assess our approach by analyzing student-created cumulative, semester-long annotated bibliographies that would potentially demonstrate students' IL competencies when choosing a topic in psychology.

Belar (2009, p. 65) emphasizes the importance of IL competencies among psychology students since the IL domain is intrinsically linked to the many ways of learning. When acquired by psychologists, these IL abilities will enable them to put into practice information analysis, critical thinking, learning or clinical practice. She concludes that "Psychology needs to be a leader in advancing the culture of competency."

The interest of psychologists in IL competencies assessment, particularly in HE environments, is not new. Some studies have gone more in-depth with respect to learning outcomes in order to know the mechanisms of IL learning while seeking to intervene on this subject (Chan, 2016; Kiel et al., 2015; Larkin and Pines, 2005; Stanoevska-Slabeva et al., 2015). Others reflect more in detail on the instruments of student performance (Neely, 2006; McKinney, 2010; Fraillon et al., 2013; Graf and Harris, 2016). Finally, others focus on the results obtained and what they mean, taking into account the learning in IL and which areas or components are evaluated (Cranney et al., 2008; Heine and O'Connor, 2013; Stecher and Hamilton, 2014).

Recognizing the transversal importance of IL competencies in an academic career and lifelong learning and inspired by the cognitive evaluation theory (CET), intrinsic motivation is based on feelings of competency and self-determination. Several studies demonstrate a connection between motivation and information processing effects (Kurbanoglu et al., 2006; Niemiec and Ryan, 2009; Van den Broeck et al., 2010; Wulf and Lewthwaite, 2016). A central component of CET is that events influencing perceptions of competency or autonomy will affect intrinsic motivation levels and the increased feelings of competency and autonomy play a vital role in sustaining and increasing intrinsic motivation (Deci and Ryan, 1985).

From the motivational perspective, "there are a number of different expectancy constructs such as self-efficacy [and] perceptions of competence" (Pintrich, 2003, p. 671). Both BI and SE are approached here. BI theory posits that "certain personality traits confer on the individual a propensity to perceive convergences and divergences between their belief that they can attain goals and the importance that they place on these goals" (Petrides and Furnham, 2015, p. 1). The theory moves in two coordinates, one of belief and the other of importance. These two coordinates generate four quadrants of hubris and depression on the one hand, and motivation and apathy on the other. From the perspective of IL, the concept of BI has been addressed in the design of the IL-HUMASS questionnaire (Pinto, 2010) and in some case studies (Pinto and Puertas, 2012; Lopes and Pinto, 2016). In relation to BI perceptions, Pinto and Puertas (2012), based on a survey of psychology students at the Spanish universities of Granada and Salamanca, found significant differences between the categories of communication, evaluation, search and processing of the information.

Within the context of social cognitive theory, SE is a well-known concept in psychology. Unlike self-regulation, which is a strategy, SE consists of a special type of belief in oneself. 
It positively relates to confidence. It also differs from self-esteem, which focuses on «being», while SE concerns "doing". According to Bandura (1977, p. 195), "expectations of personal efficacy are based on four major sources of information: performance accomplishments, vicarious experience, verbal persuasion, and physiological states." Although close, the concepts of SE and BI are different: "self-efficacy differs from [belief-in-importance] in that it is task-specific, rather than general, and concerns confidence in performing particular actions, rather than confidence in achieving broads goals" (Petrides and Furnham, 2015, p. 3). Kurbanoglu (2003, 2009) suggests that students with lower SE levels avoid challenging activities, and those with low motivation are those who are less likely to develop IL competencies. Concerning SE perceptions, Pinto and Puertas (2012) also found significant differences between the four IL categories.

Ross et al. (2016) state that the most important predictor of IL SE was intrinsic motivation to know. Recently, Rosman et al. (2018) have stated the importance of teaching IL to students at the level of their achievement. IL self-efficacy is associated with higher levels of student academic motivation. In fact, some studies have highlighted that motivation, along with SE, has a relevant role in academic achievement and performance, particularly when linked with the acquisition of IL competencies.

Based on this literature, a part of the research focuses on the motivation (BI and SE) about IL competencies among psychology students in Spain and Portugal. For a better argumentation, we propose the following hypotheses:

H1. Taken together, the levels of motivation (BI and SE) are similar between students from both countries.

H2. By competency categories, there are few significant differences concerning students' motivation (BI and SE).

H3. By individual competencies, there are quite a few significant differences in students $\mathrm{BI}$ and SE facets of motivation.

Another front of the present research refers to the sources of learning which are preferred by students. In this regard, significant differences by discipline have been detected by Hativa and Birenbaum (2000). Given the great variety of possible learning strategies, our focus is on the four ways of accessing information according to the IL-HUMASS questionnaire: directed learning in class, autonomous learning, library and specialized courses (Pinto, 2010). Previous studies reveal that the preferred SL among Portuguese psychology students is autonomous learning (Lopes and Pinto, 2016), while Spanish students select directed learning (Pinto et al., 2019, p. 222). Based on this evidence, we propose the following hypothesis.

H4. In both countries, the preferred source of learning among psychology students consists of a mix of directed - classroom - and autonomous learning.

Finally, we intend to uncover the underlying factors of the (BI and SE) motivation about IL competencies. Typically, the underlying characteristics of a set of variables are addressed using the statistical technique of factor analysis (De Coster, 1998; Taylor, 2001; Yong and Pearce, 2013). In this regard, we have found parallel works in other disciplines and environments (Pinto and Fernandez-Pascual, 2016), but not on IL perceptions of psychology students. According to our professional experience and the results of other investigations, we assume the next proposition.

H5. From an underlying perspective, there are no significant differences between countries regarding students' motivations (BI and SE) of IL competencies.
Perceptions of information literacy competencies 


\section{AJIM 73,3}

\section{Methods}

In this section, we will include details of the questionnaire as well as data collection and analysis.

\section{The questionnaire}

We think that survey-based studies are always wider in scope but shallower in terms of what they tell us about students' experiences. However, data collection through surveys can provide an interesting starting point for further qualitative inquiries based on deeper and more personal insights. IL-HUMASS consists of an attitudinal scale composed of 26 IL competency-related items that are clustered around four categories: searching, evaluation, processing and communication/dissemination of the information (Table 1); all items are viewed from the perspectives of three subjective dimensions:BI, SE and preferred SL. One-to-nine Likert scale is employed: $<5$ (low), $>5-6<$ (moderate), $>6-7<$ (normal), $>7-8<$ (high), $>8$ (excellent). The questionnaire was designed on the basis of a wide corpus of literature on IL, regarding rules of a general nature (SCONUL, 1999; ACRL, 2000; Webber and Johnson, 2006; Bruce, 2007; Corrall, 2007), as well as specific aspects of empirical user-centered research (Limberg, 2005; Maybee, 2006). In this regard, "the interplay between knowledge formation, workplace learning, and information technologies" (Tuominen et al., 2005, p. 330) is reflected in our research through the interplay between dimensions and categories. The design of IL-HUMASS was related to its priority use in Spanish and Portuguese universities and has been widely validated (Pinto, 2010; Lopes and Pinto, 2013). In the present study, IL-HUMASS showed acceptable Cronbach's alpha scores, confirming once again its reliability and

\begin{tabular}{lll}
\hline Categories & & Competencies \\
\hline \multirow{2}{*}{ Searching } & 1 & Using printed sources of information \\
& 2 & Using automated catalogues \\
& 4 & Using electronic sources of primary information \\
& 5 & Using electronic sources of secondary information \\
6 & Knowing the terminology of your subject \\
Evaluation & 7 & Searching and retrieval of Internet information \\
& 9 & Using informal electronic sources of information \\
& 10 & Knowing information search strategies \\
11 & Assessing quality of information resources \\
12 & Kecognizing author's ideas \\
13 & Determining whether information is updated \\
14 & Knowing the most relevant authors and institutions \\
15 & Schematizing and abstract information \\
16 & Recognizing text structure \\
17 & Using database managers \\
18 & Using bibliographic reference managers \\
19 & Handling statistical programs and spreadsheets \\
20 & Installing computer programs \\
21 & Communicating in public \\
22 & Communicating in other languages \\
23 & Writing a document \\
24 & Knowing the code of ethics in your field \\
25 & Knowing laws on the use of information and property \\
26 & Creating academic presentations \\
& & Disseminating information on the Internet \\
& &
\end{tabular}

Table 1.

IL-HUMASS categories and competencies
Using printed sources of information

Using automated catalogues

electronic sources of prim

Knowing the terminology of your subject

Searching and retrieval of Internet information

Knowing information search strategies

Assessing quality of information resources

Knowing the typology of scientific information sources

Determining whether information is updated

Schematizing and abstract information

Recognizing text structure

Using bibliographic reference managers

Handling statistical programs and spreadsheets

Communicating in other languages

Knowing laws on the use of information and property

Disseminating information on the Internet 
internal consistency: BI-Spain: 0.915; BI-Portugal: 0.904; SE-Spain: 0.906; SE-Portugal: 0.923 (Cronbach and Meehl, 1955).

\section{Data gathering}

There were six participating institutions: University of Granada $(N=691)$, University of Jaume I $(N=511)$ and Complutense University of Madrid $(N=982)$, all from Spain; and ISPA-Instituto Universitario $(N=556)$, University of Porto $(N=1143)$ and University of Lisbon $(N=334)$, all from Portugal. Survey implementation was carried out online, mostly in the computer lab, during the last quarter of 2017. With consent from teaching faculty and authorities, we provided the students with an explanation of the research goals. Though the sample was of convenience, the experimental scenario is broadly representative of psychology students. This facilitates the subsequent generalization of the results.

When the IL-HUMASS questionnaire was administered, 513 complete responses were obtained. The average age of the participants was 23.14 years. Distribution by institutions and gender is displayed (Table 2). Gender distribution does not show significant differences between countries (test the comparison of proportions, $p>0.05$ ). Gender parity indexes are 4.18 (Spain) and 5.28 (Portugal) (UNESCO, 2009). This profile is illustrative of the general population of psychology students.

\section{Data analysis}

To confirm or reject the stated hypotheses, we need some exploration: it mainly focuses on descriptive, variance and factor analysis. Descriptive analysis pursues the knowledge of mean scores and their distribution within the sample. For a better understanding of the IL status of psychology students, we also need to know the differences concerning the approached dimensions, categories and individual competencies. The comparison between countries permits us to know the degree of consistency between both population samples. According to the widely acknowledged statistic null hypothesis, relationships - or differences - between the variables of different groups - in our case, Portuguese and Spanish students - are significant when they are not because of chance (Keselman et al., 1998). In this regard, non-parametric Mann-Whitney $U$ test is employed. Differences are significant if $p$-value $<0.05$. In all circumstances, IBM SPSS 25 software has been used.

The main objective of factor analysis is to summarize data for the better interpretation and understanding of relationships and patterns among variables. It is normally used to regroup variables into a limited set of clusters based on shared variance. It "operates on the notion that measurable and observable variables can be reduced to fewer latent variables that share a common variance and are unobservable" (Yong and Pearce, 2013, p. 80). A factor loading for a

\begin{tabular}{|c|c|c|c|c|c|c|}
\hline Country & Institution & Male & Female & Total & $\%$ Total & \\
\hline \multirow[t]{5}{*}{ Spain } & University of Granada & 10 & 44 & 54 & & \\
\hline & University of Jaume I & 8 & 31 & 39 & & \\
\hline & University of Madrid & 26 & 105 & 131 & & \\
\hline & Total & 44 & 180 & 224 & $43.66 \%$ & \\
\hline & $\%$ Spain & $(19.6 \%)$ & $(80.4)$ & & & \\
\hline \multirow[t]{5}{*}{ Portugal } & ISPA-Instituto Universitário & 13 & 66 & 79 & & \\
\hline & University of Lisbon & 5 & 43 & 48 & & \\
\hline & University of Porto & 28 & 134 & 162 & & \\
\hline & Total & $46(15.9 \%)$ & $243(84.1 \%)$ & 289 & $56.34 \%$ & \\
\hline & $\begin{array}{l}\% \text { Portugal } \\
N\end{array}$ & 90 & 423 & 513 & $100 \%$ & $\begin{array}{r}\text { Table } 2 . \\
\text { Sample distribution }\end{array}$ \\
\hline
\end{tabular}

\section{Perceptions of information literacy competencies}

351 
AJIM 73,3

352 variable is a measure of how much the variable contributes to the factor. A better understanding of the deep factors involved in students' BI and SE of IL competencies would facilitate any pedagogical approach to the subject. To uncover these factors, methods of extraction - principal component analysis - and rotation - varimax with Kaiser's normalization - were used (DeCoster, 1998; Taylor, 2001). In any case, the naming of factors is more of an art. The only rule is to give names that best represent the variables within the factors.

\section{Findings}

After first addressing the reliability of the instrument and the scenarios of the sample, the description of overall results refers to the entire population studied; they are merely descriptive, as an introductory first step to deeper and more detailed analysis. The levels of BI and SE are analyzed, both by category of competencies and by competency. We then proceed to uncover those with significant differences, both in BI and SE, regarding gender, institution and country of the respondents. Sources of learning were also compared. Finally, we uncovered the underlying factor structures concerning IL competencies in both dimension (BI and SE) and country (Spain and Portugal).

\section{Descriptive global scores}

Overall mean scores of Spanish and Portuguese psychology students with respect to the dimensions of BI and SE are parallel in both countries (Table 3). BI scores are markedly higher and more concentrated than those of SE.

There are no significant differences between countries in the average levels (Mann-Whitney $U$ test, $p>0.05$ ), nor in the mean values (test of the median of independent samples, $p>0.05$ ).

\section{Mean scores by category}

Concerning the BI dimension, inter-country mean score differences are significant in the category of evaluation. With regard to the SE dimension, significant differences emerge in the categories of evaluation and processing (Mann-Whitney $U$ test, $p<0.05$ ) (Table 4).

The category with the highest scores in BI is communication for Spanish students and evaluation for Portuguese students. In SE, the highest scores also correspond to the evaluation category for Portuguese students and to that of communication for Spanish students. The least-rated category is that of processing, in both dimensions and countries.

Regarding gender, differences appear in Spain concerning BI (Mann-Whitney $U$ test, $p<0.05$ ), and higher scores for women in the categories of searching, processing and communication. No gender-significant differences appear in SE. In the case of Portugal, there are gender differences in the average levels in BI-communication $(\phi=0.044)$. In this case, women also score higher. Regarding SE, men score higher in the search category.

\section{Mean scores by competency}

Both BI and SE values are declared by the students in the 26 competencies, and four categories are compared. In both countries, there is great parallelism in the values of BI and

Table 3.

Descriptive results regarding the levels declared in $\mathrm{BI}$ and SE (differences by country)

\begin{tabular}{llccccc}
\hline Dimension & & Mean & Median & Std & min & $\max$ \\
\hline Global-BI & Spain & 7.84 & 7.97 & 0.77 & 4.04 & 9.00 \\
& Portugal & 7.90 & 8.00 & 0.76 & 2.48 & 9.00 \\
Global-SE & Spain & 6.42 & 6.58 & 0.98 & 3.06 & 8.47 \\
& Portugal & 6.32 & 6.46 & 0.95 & 2.32 & 9.00 \\
& & & & & &
\end{tabular}




\begin{tabular}{|c|c|c|c|c|c|c|c|c|}
\hline \multicolumn{4}{|c|}{ Belief-in-importance (BI) } & \multicolumn{4}{|c|}{ Self-efficacy (SE) } & \multirow{2}{*}{$\begin{array}{l}\text { Perceptions of } \\
\text { information }\end{array}$} \\
\hline Searching & Mean & Median & Std dev & & Mean & Median & Std dev & \\
\hline Spain & 7.67 & 7.88 & 0.91 & Spain & 6.47 & 6.50 & 1.13 & \\
\hline Portugal & 7.82 & 8.00 & 0.89 & Portugal & 6.36 & 6.50 & 1.05 & competencies \\
\hline \multicolumn{9}{|l|}{ Evaluation } \\
\hline Spain & 7.98 & 8.20 & 0.95 & Spain & 6.50 & 6.60 & 1.19 & \multirow{2}{*}{353} \\
\hline Portugal & 8.15 & 8.40 & 0.85 & Portugal & 6.74 & 6.90 & 1.08 & \\
\hline \multicolumn{9}{|l|}{ Processing } \\
\hline Spain & 7.53 & 7.67 & 1.02 & Spain & 6.11 & 6.17 & 1.26 & \multirow{5}{*}{$\begin{array}{r}\text { Table } 4 . \\
\text { Main descriptive } \\
\text { measures by category } \\
\text { and dimension: } \\
\text { comparative balance } \\
\text { between countries }\end{array}$} \\
\hline Portugal & 7.55 & 7.66 & 1.08 & Portugal & 5.70 & 5.80 & 1.22 & \\
\hline \multicolumn{8}{|l|}{ Communication } & \\
\hline Spain & 8.19 & 8.43 & 0.74 & Spain & 6.62 & 6.71 & 1.11 & \\
\hline Portugal & 8.05 & 8.14 & 0.85 & Portugal & 6.44 & 6.57 & 1.07 & \\
\hline
\end{tabular}

some differences in SE (Figure 1). Overall, the scores are slightly higher among Spanish students.

An in-depth analysis of differences between countries focuses our attention on the competencies and dimensions in which they are statistically significant: seven in the BI dimension. With respect to SE, there are 14 differences and, among them, are the seven previously mentioned. Thus, it is confirmed that $\mathrm{SE}$ is the dimension in which there are more significant differences $(\phi$ values $\leq 0.05)$ among students. These differences are distributed among the four categories. The country with the lower mean score is also displayed (Table 5). Ultimately, differences by country should be expected, given the cultural and/or curricular variations. Thus, for example, in c21-communicating in other languages, the Portuguese participants declare a high SE, as opposed to the Spanish, who feel less able to express themselves in another language. In c16 - using database managers (Access, MySQL, etc.), the future Spanish psychologists have received specific training in some optional discipline, while this is not the case of the studies in Portugal.

\section{Sources of learning}

Overall the preferred SL for IL competencies are classroom and self-learning. Libraries and specific courses are noticeably less demanded (Table 6 and Table A1 (annex)).

These results reveal an inclination to the mix of classroom and autonomous learning. In any case, some differences between countries emerge in the four learning sources: self/ learning, classroom, library and specific courses. The most striking thing is the low preference of students for the library as a SL.

\section{Latent structures}

To determine the underlying structures by country, confirmatory factor analysis was applied (Van Helvoort et al., 2017). This procedure had previously been used by Mackey and Ho (2005), to identify dimensions of IL and information technologies; by ChanLin (2009) in library and information science (LIS) undergraduates; or by Pinto et al. (2016), who present a largescale study involving IL perceptions among social science students. In both populations, Kaiser-Meyer-Olkin (KMO) scores endorse the sample adequacy for factor analysis to be applied. Following Kaiser's criterion, a factor is included when its eigenvalue is greater than 1.0 (Field, 2013; Hair et al., 2010).

Main features of the resulting models for dimensions (BI and SE) and countries (Spain and Portugal), including percentages of variance explained (Table 7). 
AJIM

73,3

\section{4}

Figure 1.

BI and SE: Behavior in Spain and Portugal

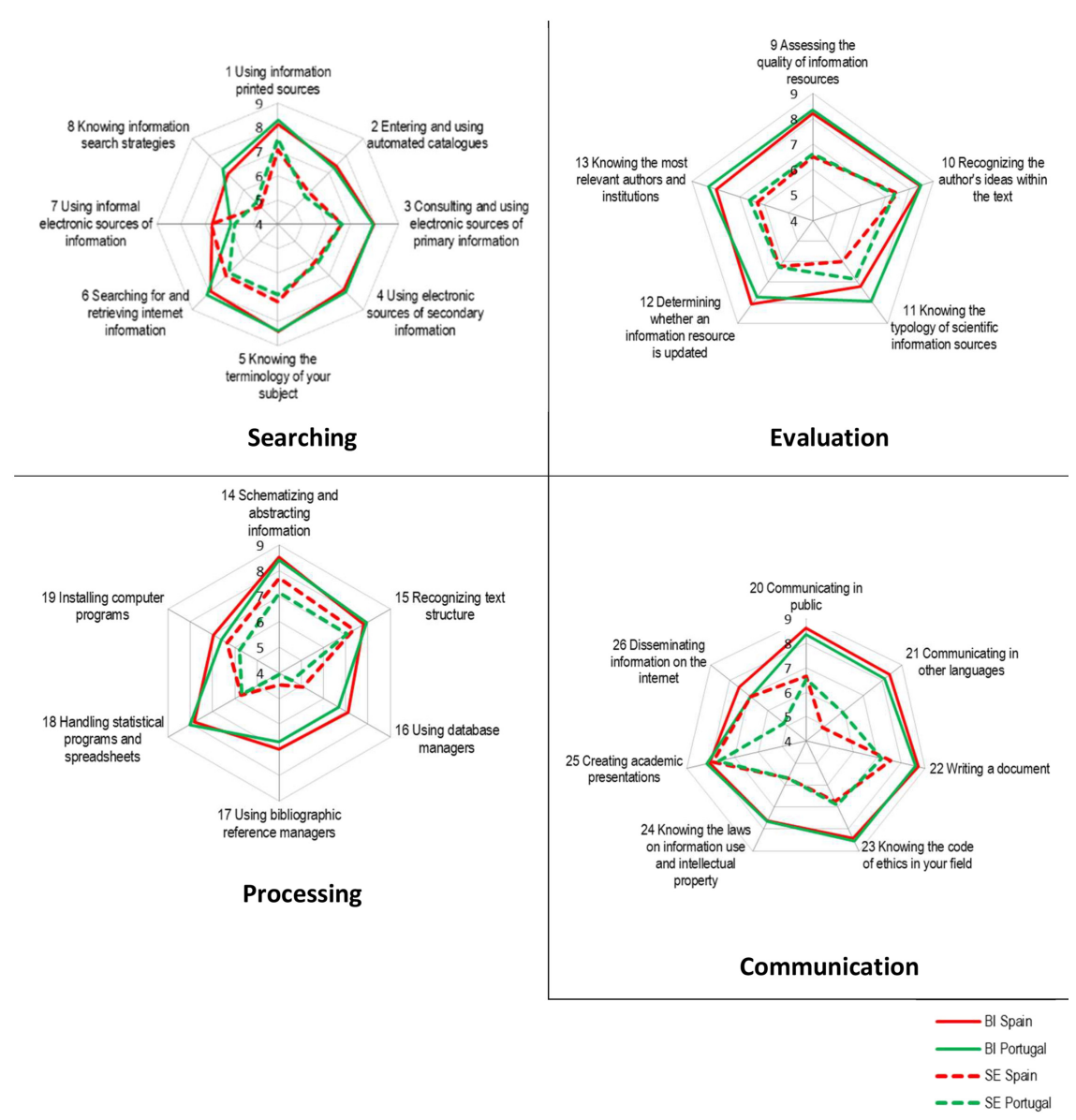

Results show that the most valued factor among Spanish students is searching, while for Portuguese students, it is evaluation. In both dimensions (BI and SE), the factors show a similar composition (Tables 7-8). Details regarding factor loadings and their accumulated variances concerning BI and SE models are displayed (Tables A2-A5 (annex)).

Underlying factor structures are consistent with the IL-HUMASS categories (searching, evaluation, processing and communication). However, in the factor structures corresponding to $\mathrm{BI}$, the category of communication is represented by the factor on communication and dissemination using ICT. In addition, there emerges the factor on ethical and legal issues of information. In the dimension of SE, each category of the questionnaire is represented by a factor. Two new factors also emerge: one related to dissemination using ICT and ethical and legal issues of information, and the other on processing using ICT. As can be observed, the factors have the same components within each dimension, which confirms the consistency of the factorial structures in both countries.

\section{Discussion}

This research is significant because it offers a diagnosis of the perceptions of students concerning motivation and their preferred sources of learning. The results can help to orient 


\begin{tabular}{|c|c|c|c|c|c|}
\hline \multirow[b]{2}{*}{ Category } & \multirow[b]{2}{*}{ Competency } & \multicolumn{2}{|c|}{$p$ values } & \multirow{2}{*}{$\begin{array}{l}\text { Country with lower } \\
\text { mean score }\end{array}$} & erceptions of \\
\hline & & $\mathrm{BI}$ & SE & & information \\
\hline \multirow[t]{3}{*}{ Searching } & $\begin{array}{l}\text { 1. Using printed sources of information (books, } \\
\text { papers, etc.) }\end{array}$ & $(0.049)$ & $(0.002)$ & Spain & competencies \\
\hline & 5. Knowing the terminology of your subject & - & $(0.001)$ & Portugal & \\
\hline & $\begin{array}{l}\text { 7. Using informal electronic sources of } \\
\text { information (blogs, discussion lists, etc.) }\end{array}$ & $(0.000)$ & $(0.012)$ & Portugal & 355 \\
\hline \multirow[t]{2}{*}{ Evaluation } & $\begin{array}{l}\text { 11. Knowing the typology of scientific } \\
\text { information sources (thesis, proceedings, etc.) }\end{array}$ & $(0.001)$ & $(0.036)$ & Spain & \\
\hline & $\begin{array}{l}\text { 13. Knowing the most relevant authors and } \\
\text { institutions within your subject area }\end{array}$ & $(0.001)$ & $(0.000)$ & Spain & \\
\hline \multirow[t]{5}{*}{ Processing } & 14. Schematizing and abstract information & - & $(0.001)$ & Portugal & \\
\hline & 15. Recognizing text structure & - & $(0.012)$ & Portugal & \\
\hline & $\begin{array}{l}\text { 16. Using database managers (Access, MySQL, } \\
\text { etc.) }\end{array}$ & $(0.002)$ & $(0.010)$ & Portugal & \\
\hline & $\begin{array}{l}\text { 17. Using bibliographic reference managers } \\
\text { (Endnote, Reference Manager, etc.) }\end{array}$ & - & $(0.000)$ & Portugal & \\
\hline & 19. Installing computer programs & - & $(0.007)$ & Portugal & \\
\hline \multirow[t]{4}{*}{ Communication } & 21. Communicating in other languages & $(0.001)$ & $(0.000)$ & Portugal (BI)/Spain & \multirow{4}{*}{$\begin{array}{r}\text { Table } 5 . \\
\text { Competencies with } \\
\text { significant differences } \\
\text { by country (Mann- } \\
\text { Whitney } U \text { test, } \\
\text { p-values } \leq 0.05 \text { in } \\
\text { brackets) }\end{array}$} \\
\hline & $\begin{array}{l}\text { 22. Writing a document (report, academic work, } \\
\text { etc.) }\end{array}$ & - & $(0.011)$ & $\begin{array}{l}\text { (SE) } \\
\text { Portugal }\end{array}$ & \\
\hline & $\begin{array}{l}\text { 25. Creating academic presentations } \\
\text { (PowerPoint, etc.) }\end{array}$ & - & $(0.015)$ & Portugal & \\
\hline & $\begin{array}{l}\text { 26. Disseminating information on the internet } \\
\text { (webs, blogs, etc.) }\end{array}$ & $(0.007)$ & $(0.010)$ & Portugal & \\
\hline
\end{tabular}

\begin{tabular}{|c|c|c|c|c|c|}
\hline \multicolumn{6}{|c|}{ Source of learning $(\%)$} \\
\hline Country & Self-learning & Classroom & Library & Specific courses & Table 6. \\
\hline Spain & 43.4 & 47.6 & 5.7 & 3.3 & sources of learning by \\
\hline Portugal & 56.0 & 29.0 & 8.2 & 6.8 & country \\
\hline
\end{tabular}

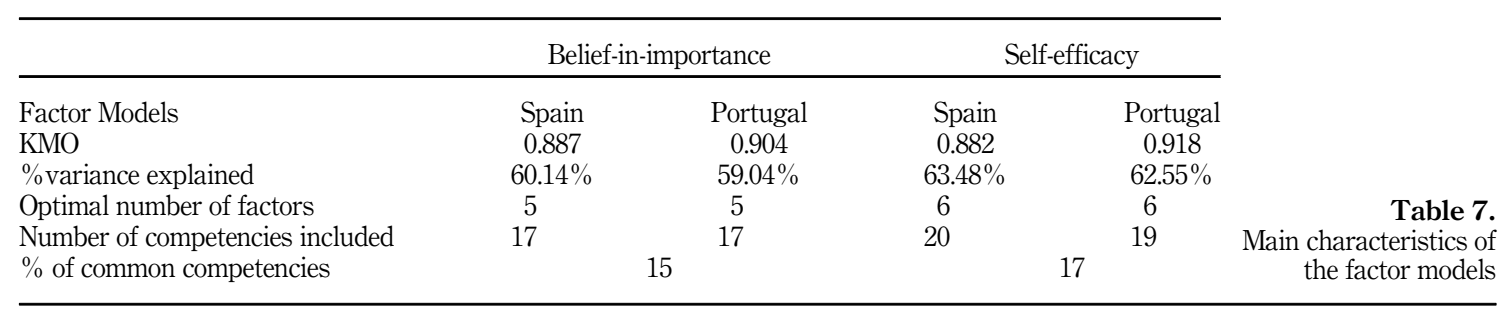

not only the motivational processes but also the formative ones related to the IL competencies. Ultimately, motivation, learning and teaching are dramatically linked, "demonstrating the utility of considering both motivation and cognition simultaneously" (Pintrich, 2003, p. 682).

No similar research has been found, thus indicating that this is probably the first evidencebased study on perceptions of IL competencies among future psychology professionals. This research's added value consists of a better understanding of IL competency perceptions among Spanish and Portuguese psychology students. In line with the research hypotheses, 
AJIM
73,3

AJIM
73,3

Table 8.

Structure and sequence of factors by dimension and country (in italic, emerging factors)

\begin{tabular}{|c|c|c|c|}
\hline $\mathrm{BI}$ & & $\mathrm{SE}$ & \\
\hline Spain & Portugal & Spain & Portugal \\
\hline F1-Searching & F1-Evaluation & F1-Searching & F1-Evaluation \\
\hline F2-Evaluation & $\begin{array}{l}\text { F2-Ethical and legal } \\
\text { issues of information }\end{array}$ & $\begin{array}{l}\text { F2- Dissemination using } \\
\text { ICT and Ethical and legal } \\
\text { issues of information }\end{array}$ & $\begin{array}{l}\text { F2- Dissemination using } \\
\text { ICT and ethical and legal } \\
\text { issues of information }\end{array}$ \\
\hline $\begin{array}{l}\text { F3- Communication } \\
\text { and dissemination } \\
\text { using ICT }\end{array}$ & $\begin{array}{l}\text { F3- Communication } \\
\text { and dissemination } \\
\text { using ICT }\end{array}$ & F3-Processing using ICT & F3-Searching \\
\hline F4-Ethical and legal & F4-Processing & F4-Processing & F4-Processing \\
\hline F5-Processing & F5-Searching & $\begin{array}{l}\text { F5-Evaluation } \\
\text { F6-Communication }\end{array}$ & $\begin{array}{l}\text { F5-Communication } \\
\text { F6-Processing using ICT }\end{array}$ \\
\hline
\end{tabular}

this section aims to verify the degree of fit between such premises and the results obtained. H1 hypothesis fits in its entirety. Regarding overall scores, there are no significant differences between the BI and SE perceptions of psychology students from the two countries. However, $\mathrm{BI}$ scores are higher than the SE.

Hypothesis H2 is also fulfilled, since by categories - average scores - significant differences by country between the BI and SE perceptions of psychology students emerge. Such perceptions are higher in the communication category, yet only for Spanish students. In Portugal, perceptions of SE are higher in the evaluation. In both dimension and country, they are lower in the processing category. Considering the improvement of student motivation, we should concentrate on this least valued category. Regarding gender differences by country, in Spain, a comparison of BI and SE scores reveals that these variations emerge in $\mathrm{BI}$ - searching, processing and communication - yet not on the SE scale. Differences in BI were also found by Pinto et al. (2018) since the category of communication-dissemination showed significant differences among social science students. In Portugal, significant differences in BI of communication - higher scores for women - and SE in searching - men scoring higher - were revealed.

Hypothesis $\mathrm{H} 3$ is also true. By competency, there are quite a few significant differences in the dimensions of BI and SE among psychology students. Differences by country emerge in the four categories and affect 14 competencies (Table 5). We should focus on the least-valued competencies that show the greatest significant variations between countries. For Spanish students, these competences are: using printed sources of information books, papers, etc.) - (1), knowing the typology of scientific information sources (thesis, proceedings, etc.) - (11) and knowing the most relevant authors and institutions within your subject area(13). They are cognitive competences. For the Portuguese students, they are the following: using informal electronic sources of information (blogs, discussion lists, etc.) - (7), using database managers (Access, MySQL, etc.) - (16) and disseminating information on the Internet (webs, blogs, etc.) - (26). They are technological competencies. Given their lower evaluation and greater variance, it is precisely these competencies that require greater assistance.

With regard to preferred sources of learning (SL), the hypothesis presented is confirmed: students of both countries prefer a mixture of classroom and autonomous learning, although the proportion of the combination varies slightly in each case. Among Portuguese students, self-learning slightly predominates over classroom learning, the opposite being true for Spanish students since they prefer the classroom. What does not vary is the low evaluation of the library as a preferred SL. This outcome may be due to the students' lack of understanding of libraries' operational complexities (Head, 2008) and to the fact that IL is no longer an exclusive domain of the library and information professionals (Brady and Malik, 2019). 
From an underlying perspective, factor structures do not differ by country. Therefore, hypothesis $\mathrm{H} 5$ holds. Nevertheless, there are differences in the dimensions due to the emergence of some factors that are independent of the categories of the questionnaire (Tables 1,7 and 8). We will distinguish between BI factors and SE factors. Concerning BI, the emerging factors are in communication and dissemination using ICT, and ethical and legal issues of information. From this latent perspective, we know that, besides the competencies of searching, evaluation and processing of information, students give importance not only to the new version of communication-dissemination of information through ICT technologies but also to the problems that from the ethical and legal point of view come up in these new scenarios. Both emerging factors coincide with the guidelines of APA (2006), EuroPsy (2011) and IAAP and UPsyS (2016), since these also distinguish major goals in the areas of communication and that of ethical and legal information. In the case of SE, one of the two emerging factors is on dissemination using ICT and ethical and legal issues of information. This SE's factor reflects the concern of students when making the use of such ICT technologies compatible with the ethical and legal values in the use of information. The other SE's factor refers to processing using ICT. Students value expertise in the technological processing of information. This factor agrees with the results of similar studies in which a distinction is made between cognitive processing - human - and technological processing (ICT) (Pinto et al., 2019). In summary, it is these emerging factors that should be the priority focus.

This study offers a diagnosis of the motivational status of IL among psychology students. Looking at the practice, the weaknesses found call for promoting some improvement initiatives, which should center on first-year students. As a summary, we suggest motivational improvement in the following topics, grouped by individual competencies, categories and emerging factors (Table 9).

Concerning learning habits, this research highlights some shortcomings, including the low value of the library as a source of learning IL competencies (Table 6). In this regard, we suggest promoting improvement in the following issues:

\begin{tabular}{|c|c|c|c|}
\hline & Country & Dimension & Topic \\
\hline \multirow{5}{*}{$\begin{array}{l}\text { Individual } \\
\text { competencies }\end{array}$} & \multirow[t]{2}{*}{ Spain } & \multirow[t]{5}{*}{$\mathrm{BI}$ and SE } & Using printed sources of information (books, papers, etc.) \\
\hline & & & $\begin{array}{l}\text { Knowing the typology of scientific information sources } \\
\text { (thesis, proceedings, etc.) } \\
\text { Knowing the most relevant authors and institutions } \\
\text { within your subject area }\end{array}$ \\
\hline & \multirow[t]{3}{*}{ Portugal } & & $\begin{array}{l}\text { Using informal electronic sources of information (blogs, } \\
\text { discussion lists, etc.) }\end{array}$ \\
\hline & & & Using database managers (Access, MySQL, , etc ) \\
\hline & & & $\begin{array}{l}\text { Disseminating information on the Internet (webs, blogs, } \\
\text { etc.) }\end{array}$ \\
\hline Categories & $\begin{array}{l}\text { Spain and } \\
\text { Portugal }\end{array}$ & $\mathrm{BI}$ and SE & Processing of information \\
\hline \multirow[t]{5}{*}{ Emerging factors } & \multirow{5}{*}{$\begin{array}{l}\text { Spain and } \\
\text { Portugal }\end{array}$} & \multirow[t]{3}{*}{ BI } & Ethical and legal issues of information: updating of \\
\hline & & & $\begin{array}{l}\text { information, quality assessment of information, } \\
\text { plagiarism and the use of information }\end{array}$ \\
\hline & & & $\begin{array}{l}\text { Communication and dissemination using ICT: create } \\
\text { academic presentations, disseminate information on the } \\
\text { Internet }\end{array}$ \\
\hline & & \multirow[t]{2}{*}{$\mathrm{SE}$} & $\begin{array}{l}\text { Dissemination using ICT and ethical and legal issues of } \\
\text { information: computer ethics }\end{array}$ \\
\hline & & & $\begin{array}{l}\text { Processing using ICT: database managers, bibliographic } \\
\text { reference managers, statistical programs and } \\
\text { spreadsheets, information search strategies }\end{array}$ \\
\hline
\end{tabular}

\section{Perceptions of information literacy competencies}

357
Table 9. Suggestions for improvement by competencies, categories and emerging factors 
AJIM

73,3
(1) Valuing in-class learning among Portuguese students

(2) Promoting self-learning among Spanish students

(3) Use of the library as a key service

\section{Limitations and future research}

Given that IL depends on cultural contexts, the results found here represent the communities and discipline addressed. This quantitative research was limited to a series of standard competencies of IL (SCONUL, 1999; ACRL, 2000). But the reconceptualization of IL (SCONUL, 2011; ACRL, 2016; CILIP Information Literacy Group, 2018), together with phenomenological approaches to learning, demands additional, more in-depth qualitative exploration. From this viewpoint, the methodology of focus groups is a tool used extensively in the field of psychology since it permits the direct interactions between the group and the interviewers (Brown, 2018). It yields significant data to directly understand the dynamics of the groups, their motivations and the procedural aspects they are experiencing. This way, knowledge of student motivation could be broadened. Ultimately, there is a "need for more research to examine the role of motivational constructs in more constructivist classroom environments" (Pintrich, 2003, p. 682).

Though first-cycle students are especially needed for research, it would also be of interest to expand the sample considering students of all levels (first cycle, second and master) of the Bologna curriculum. Likewise, a comparison of the BI and SE self-perceptions in IL competencies with the real levels of knowledge could be approached. Other possible research could ponder the relationship between the IL curricula and the levels of BI and SE declared by the students.

\section{Conclusions}

Considering a representative sample of psychology students in Spain and Portugal, this work contributes to the literature on IL, as it enriches the knowledge about two facets of motivation, $\mathrm{BI}$ and SE. With respect to these two constructs, the students demonstrate acceptable, although improvable, levels, especially in SE, with a high degree of homogeneity between the two countries. The values of BI prevail over those of SE. Nevertheless, there are significant differences that are randomly distributed among the categories and competencies. The greatest number of these differences is generated at the level of individual competencies. Initiatives aimed at improvement of motivation should focus on SE and on the category least valued by students, which is that of processing, and also on the seven competencies that have shown the greatest variability. Academic and/or curricular initiatives should foster awareness of BI and self-esteem on SE.

We have found a high degree of consistency in the underlying structures of the two constructs on motivation about IL competencies. From this latent perspective, the factorial structures contemplate the categories of the IL-HUMASS questionnaire. Yet other emerging factors are incorporated, both in BI and SE, which deserve special attention.

From the perspective of learning habits, students show similar patterns in both countries, with the predominance of a mix of classroom and autonomous learning. Nevertheless, the library is hardly valued. We recommend a strategic promotion of the values of the library as a support for learning processes. The library itself has to know these findings on students' perceptions, having to design motivational and instructional initiatives. Though traditionally resource-centered, the library must be reconfigured as a digital service center. Open dialogue between librarians and faculty should enhance students' understanding of the library values.

Since this research is of quantitative nature, it should be complemented with other qualitative studies of a phenomenological kind. 


\section{References}

ACRL (2000), "Information literacy competency standards for higher education", available at: http:// www.ala.org/acrl/standards/informationliteracycompetency (accessed 20 February 2020).

ACRL (2010), "Psychology information literacy standards", available at: http://www.ala.org/acrl/ standards/psych_info_lit (accessed 20 February 2020).

ACRL (2016), "Framework for information literacy for higher education", available at: http://www.ala. org/acrl/standards/ilframework (acessed 9 September 2020).

APA (2002), APA Guidelines on Multicultural Education, Training, Research, Practice, and Organizational Change for Psychologists, American Psychological Association, Washington, DC.

APA (2006), "APA task force on the assessment of competence in professional psychology: final report”, available at: https://www.apa.org/ed/resources/competency-revised.pdf (accessed 20 February 2020).

APA (2013), "APA guidelines for the undergraduate psychology major. Version 2.0: APA board of educational affairs task force on psychology major competencies", available at: https://www. apa.org/ed/precollege/about/psymajor-guidelines.pdf (accessed 20 February 2020).

APA (2016), "Guidelines for the undergraduate psychology major: version 2.0", American Psychologist, Vol. 71 No. 2, pp. 102-111.

Bandura, A. (1977), "Self-efficacy: toward a unifying theory of behavioral change", Psychological Review, Vol. 84 No. 2, pp. 191-215.

Belar, C. (2009), "Advancing the culture of competence", Training and Education in Professional Psychology, Vol. 3 No. 4 Supplement, pp. 63-65.

Birkett, M. and Hughes, A. (2013), "A collaborative project to integrate information literacy”, Learning and Teaching, Vol. 12 No. 1, pp. 96-100.

Brady, L. and Malik, M. (2019), "Science, story, and structure: framing the conversation for psychology faculty and librarian information literacy collaboration”, Teaching of Psychology, Vol. 46 No. 1, pp. 64-71.

Brown, J. (2018), "Interviews, focus groups and Delphi techniques", in Brough, P. (Ed.), Advanced Research Methods for Applied Psychology: Design, Analysis and Reporting, Routledge, London, pp. 95-106.

Bruce, C. (2007), The Seven Faces of Information Literacy, Auslib Press, Adelaide.

Chan, C. (2016), "Institutional assessment of student information literacy ability: a case study", Communications in Information Literacy, Vol. 10 No. 1, pp. 50-61.

ChanLin, L.J. (2009), "Development of a competency questionnaire for LIS undergraduates at Fu-Jen Catholic University", Journal of Educational Media and Library Sciences, Vol. 47 No. 1, pp. 5-17.

CILIP Information Literacy Group (2018), “CILIP definition of information literacy 2018”, available at: https://infolit.org.uk/ILdefinitionCILIP2018.pdf (accessed 9 September 2020).

Corrall, S. (2007), "Benchmarking strategic engagement with information literacy in higher education: towards a working model", Information Research, Vol. 12 No. 4, paper 328, available at: http:// informationr.net/ir/12-4/paper328.html.

Cranney, J., Morris, S., Spehar, B. and Scoufis, M. (2008), "Helping first year students think like psychologists: supporting information literacy and teamwork skill development", Psychology Learning and Teaching, Vol. 7 No. 1, pp. 28-36.

Cronbach, L. and Meehl, P. (1955), "Construct validity in psychological tests", Psychological Bulletin, Vol. 52 No. 4, pp. 281-302.

Deci, E. and Ryan, R. (1985), Intrinsic Motivation and Self-Determination in Human Behavior, Plenum Press, New York.

DeCoster, J. (1998), “Overview of factor analysis”, available at: http://www.stat-help.com/notes.html (acessed 7 July 2020).

Perceptions of information literacy competencies

$-$ 
EuroPsy (2011), "EuroPsy: the European certificate in psychology", available at: http://www.europsyefpa.eu (accessed 20 February 2020).

Eurydice (2005), Focus on the Structure of Higher Education in Europe, 2004-05: National Trends in the Bologna Process, Eurydice European Unit, Brussels.

Farkas, M. (2012), "Participatory technologies, pedagogy 2.0 and information literacy", Library Hi Tech, Vol. 30 No. 1, pp. 82-94.

Field, A. (2013), Discovering Statistics Using IBM SPSS Statistic, 4th ed., Sage, Los Angeles.

Fraillon, J., Schulz, W. and Ainley, J. (2013), International Computer and Information Literacy Study: Assessment Framework, International Association for the Evaluation of Educational Achievement, Amsterdam.

Graf, A. and Harris, B. (2016), "Reflective assessment: opportunities and challenges", Reference Services Review, Vol. 44 No. 1, pp. 38-47.

Grafstein, A. (2002), "A discipline-based approach to information literacy", Journal of Academic Librarianship, Vol. 28 No. 4, pp. 197-204.

Hair, J., Black, W. and Babin, B. (2010), Multivariate Data Analysis: A Global Perspective, 7th ed., Pearson Prentice Hall, New Jersey.

Hativa, N. and Birenbaum, M. (2000), "Who prefers what? Disciplinary differences in students' preferred approaches to teaching and learning styles", Research in Higher Education, Vol. 41 No. 2, pp. 209-236.

Head, A. (2008), "Information literacy from the trenches: how do humanities and social sciences majors conduct academic research?", College and Research Libraries, Vol. 69 No. 5, pp. 427-446.

Heine, C. and O'Connor, D. (2013), Teaching Information Fluency: How to Teach Students to Be Efficient, Ethical, and Critical Information Consumers, Scarecrow Press, Lanham.

IAAP and UPsyS (2016), "International declaration of core competencies in professional psychology", available at: http://www.iupsys.net/dotAsset/1fd6486e-b3d5-4185-97d0-71f512c42c8f.pdf (accessed 22 May 2019).

Kaslow, N. (2004), "Competencies in professional psychology", American Psychologist, Vol. 59 No. 8, pp. 774-781.

Keselman, H.J., Huberty, C.J., Lix, L.M., Olejnik, S., Cribbie, R.A., Donahue, B., Kowalchuk, R.K., Lowman, L.L., Petoskey, M.D., Keselman, J.C. and Levin, J.R. (1998), "Statistical practices of educational researchers: an analysis of their ANOVA, MANOVA, and ANCOVA analyses", Review of Educational Research, Vol. 68 No. 3, pp. 350-386.

Kiel, S., Burclaff, N. and Johnson, C. (2015), "Learning by doing: developing a baseline information literacy assessment”, Portal: Libraries and the Academy, Vol. 15 No. 4, pp. 747-766.

Kurbanoglu, S., Akkoyunlu, B. and Umay, A. (2006), "Developing the information literacy self-efficacy scale", Journal of Documentation, Vol. 62 No. 6, pp. 730-743.

Kurbanoglu, S. (2003), "Self-efficacy: a concept closely linked to information literacy and lifelong learning", Journal of Documentation, Vol. 59, pp. 635-646.

Kurbanoglu, S. (2009), "Self-efficacy: an alternative approach to the evaluation of information literacy", Qualitative and Quantitative Methods in Libraries Theory and Applications: Proceedings of the International Conference on QQML2009, World Scientific, Singapore, pp. 323-328.

Larkin, J. and Pines, H. (2005), "Developing information literacy and research skills in introductory psychology: a case study", Journal of Academic Librarianship, Vol. 31 No. 1, pp. 40-45.

Limberg, L., Alexandersson, M., Lantz-Andersson, A. and Folkesson, L. (2008), "What matters? Shaping meaningful learning through teaching information literacy", Libri, Vol. 58 No. 2, pp. 82-91.

Limberg, L. (2005), "Informing information literacy education through empirical research", in Henri, J. and Asselin, M. (Eds), The Information Literate School Community 2: Issues of Leadership, Charles Sturt University, Wagga Wagga, pp. 39-50. 
Lopes, C. and Pinto, M. (2013), "Desenho e construção do questionário de literacia da informação no ensino superior - IL-HUMASS: estudo qualitativo (Parte l)", Cadernos BAD, Vols 1/2, pp. 123-139.

Lopes, C. and Pinto, M. (2016), "Autoavaliação das competências de informação em estudantes universitários - IL-HUMASS: estudo quantitativo (Parte II)", Cadernos BAD, Vol. 1, pp. 34-62.

Mackey, T.P. and Ho, J. (2005), "Implementing a convergent model for information literacy: combining research and web literacy", Journal of Information Science, Vol. 31 No. 6, pp. 541-555.

Maybee, C. (2006), "Undergraduate perceptions of information use: the basis for creating user-centered student information literacy instruction”, Journal of Academic Librarianship, Vol. 32 No. 1, pp. 79-85.

McKinney, P. (2010), Inquiry-based Learning and Information Literacy: A Meta-Analytical Study, CILASS, Sheffield.

Neely, T. (2006), Information Literacy Assessment: Standards-Based Tools and Assignments, American Library Association, Chicago.

Niemiec, C. and Ryan, R. (2009), "Autonomy, competence, and relatedness in the classroom: applying self-determination theory to educational practice", Theory and Research in Education, Vol. 7 No. 2, pp. 133-44.

Petrides, K.V. and Furnham, A. (2015), "Further tests of belief importance theory", PloS One, Vol. 10 No. 4, pp. 1-14.

Pinto, M. and Fernández-Pascual, R. (2016), "Exploring LIS students' beliefs in importance and selfefficacy of core information literacy competencies", College and Research Libraries, Vol. 77 No. 6, pp. 703-726.

Pinto, M. and Puertas, S. (2012), "Autoevaluación de la competencia informacional en los estudios de Psicología desde la percepción del estudiante”, Anales de Documentación, Vol. 15 No. 2, pp. 1-15.

Pinto, M., Fernández-Pascual, R., Gómez-Hernández, J.A., Cuevas, A., Granell, X. and Puertas, S. (2016), "Attitudes toward information competency of university students in social sciences", Portal: Libraries and the Academy, Vol. 16 No. 4, pp. 737-761.

Pinto, M., Fernández-Pascual, R. and Sales, D. (2018), "Communication of information in the digital age among social sciences students: uncovering a synthetic indicator of performance", Aslib, Journal of Information Management, Vol. 70 No. 4, pp. 326-343.

Pinto, M., Fernández Pascual, R. and García Marco, J. (2019a), "Self-learning of information literacy competencies in higher education: the perspective of social sciences students", College and Research Libraries, Vol. 80 No. 2, pp. 215-237.

Pinto, M., Sales, D. and Fernandez Pascual, R. (2019b), "Gender perspective on information literacy: an interdisciplinary and multidimensional analysis within higher education settings", Library and Information Science Research, Vol. 41 No. 4, pp. 1-12.

Pinto, M. (2010), "Design of the IL-HUMASS survey on information literacy in higher education: a selfassessment approach", Journal of Information Science, Vol. 36 No. 1, pp. 86-103.

Pintrich, P.R. (2003), "A motivational science perspective on the role of student motivation in learning and teaching contexts", Journal of Educational Psychology, Vol. 95 No. 4, pp. 667-686.

QAA (2016), "Subject benchmark statement: psychology", available at: http://dera.ioe.ac.uk/27668/1/ SBS-Psychology-16.pdf (accessed 22 October 2019).

Rosman, T., Peter, J., Mayer, A.K. and Krampen, G. (2018), "Conceptions of scientific knowledge influence learning of academic skills: epistemic beliefs and the efficacy of information literacy instruction”, Studies in Higher Education, Vol. 43 No. 1, pp. 96-113.

Ross, M., Perkins, H. and Bodey, K. (2016), "Academic motivation and information literacy selfefficacy: the importance of a simple desire to know", Library and Information Science Research, Vol. 38 No. 1, pp. 2-9.

Schmidt-Hanbidge, A., Tin, T. and Sanderson, N. (2018), "Information literacy skills on the go: mobile learning innovation", Journal of Information Literacy, Vol. 12 No. 1, pp. 118-136.
Perceptions of information literacy competencies 
SCONUL (1999), "Information skills in higher education: a SCONUL position paper", available at: www.sconul.ac.uk/sites/default/files/documents/Seven_pillars2.pdf (accessed 22 October 2019).

SCONUL Working Group on Information Literacy (2011), "The SCONUL seven pillars of information literacy: core model for higher education", available at: https://senseandreference.files. wordpress.com/2016/12/coremodel.pdf (accessed 9 September 2020).

Stanoevska-Slabeva, K., Müller, S., Seufert, S. and Scheffler, N. (2015), "Towards modeling and measuring information literacy in secondary education", ICIS 2015: thirty sixth International Conference on Information Systems, Forth Worth, 2015, available online at available at: https:// aisel.aisnet.org/icis2015/proceedings/ISedu/10/ (accessed 22 October 2019).

Stecher, B. and Hamilton, L. (2014), Measuring Hard-To-Measure Student Competencies: A Research and Development Plan, Rand Corporation, Santa Monica, available at: http://www.rand.org/ pubs/research_reports/RR863.html?utm_source=t.co\&utm_medium=rand_social (accessed 22 October 2019).

Taylor, A. (2001), "A brief introduction to factor analysis", Journal of Chemical Information and Modeling, Vol. 53, p. 160.

Tuominen, K., Savolainen, R. and Talja, S. (2005), "Information literacy as a sociotechnical practice", Library Quarterly, Vol. 75 No. 3, pp. 329-345.

UNESCO (2009), Education Indicators: Technical Guidelines, UNESCO, New York.

Van den Broeck, A., Vansteenkiste, M., De Witte, H., Soenens, B. and Lens, W. (2010), “Capturing autonomy, competence, and relatedness at work: construction and initial validation of the workrelated basic need satisfaction scale", Journal of Occupational and Organizational Psychology, Vol. 83 No. 4, pp. 981-1002.

Van Helvoort, J., Brand-Gruwel, S., Huysmans, F. and Sjoer, E. (2017), "Reliability and validity test of a scoring rubric for information literacy", Journal of Documentation, Vol. 73 No. 2, pp. 305-316.

Webber, S. and Johnson, B. (2006), "Working towards the information literate university", in Walton, G. and Pope, A. (Eds), Information Literacy: Recognising the Need, Chandos, Oxford, pp. 47-58.

Wulf, G. and Lewthwaite, R. (2016), "Optimizing performance through intrinsic motivation and attention for learning: the OPTIMAL theory of motor learning", Psychonomic Bulletin and Review, Vol. 23 No. 5, pp. 1382-1414.

Yong, A.G. and Pearce, S. (2013), "A beginner's guide to factor analysis: focusing on exploratory factor analysis”, Tutorials in Quantitative Methods for Psychology, Vol. 9 No. 2, pp. 79-94.

\section{Corresponding author}

Carlos Lopes can be contacted at: clopes@ispa.pt 
Annex

Perceptions of

information literacy

\begin{tabular}{|c|c|c|c|c|c|c|}
\hline \multirow[b]{2}{*}{ Country } & \multirow[b]{2}{*}{ Category } & \multirow[b]{2}{*}{ Self-learning } & \multicolumn{2}{|c|}{ Source of learning \% } & \multirow[b]{2}{*}{ Specific courses } & \multirow{2}{*}{$\begin{array}{r}\text { literacy } \\
\text { competencies }\end{array}$} \\
\hline & & & Classroom & Library & & \\
\hline \multirow[t]{5}{*}{ Spain } & Search & 39.2 & 44.8 & 13.6 & 2.4 & \\
\hline & Evaluation & 41.3 & 52.5 & 4.3 & 1.9 & 363 \\
\hline & Processing & 48.0 & 44.5 & 3.7 & 3.8 & \\
\hline & Communication & 45.0 & 48.5 & 1.2 & 5.3 & \\
\hline & Global & 43.4 & 47.6 & 5.7 & 3.3 & \\
\hline \multirow[t]{5}{*}{ Portugal } & Search & 55.9 & 18.8 & 20.2 & 5.1 & Table A \\
\hline & Evaluation & 52.8 & 33.4 & 8.4 & 5.4 & Preferences $(\%)$ for the \\
\hline & Processing & 60.7 & 29.1 & 3.1 & 7.1 & sources of learning by \\
\hline & Communication & 54.6 & 34.8 & 1.1 & 9.5 & competency categol \\
\hline & Global & 56.0 & 29.0 & 8.2 & 6.8 & and count \\
\hline
\end{tabular}

\begin{tabular}{|c|c|c|c|c|c|c|c|}
\hline $\begin{array}{l}\text { IL-HUMASS } \\
\text { category }\end{array}$ & Competency & $\begin{array}{c}\mathrm{F} 1- \\
\text { searching }\end{array}$ & $\begin{array}{c}\mathrm{F} 2- \\
\text { evaluation }\end{array}$ & $\begin{array}{c}\text { I Spain loading fa } \\
\text { F3 - } \\
\text { communication } \\
\text { and } \\
\text { dissemination } \\
\text { ICT }\end{array}$ & $\begin{array}{l}\text { ors } \\
\text { F4 - ethical } \\
\text { and legal } \\
\text { issues of } \\
\text { information }\end{array}$ & $\begin{array}{c}\text { F5 - } \\
\text { processing }\end{array}$ & \\
\hline \multirow{4}{*}{ Searching } & $\mathrm{c} 1$ & 0.648 & & & & & \\
\hline & $\mathrm{c} 2$ & 0.584 & & & & & \\
\hline & c3 & 0.785 & & & & & \\
\hline & c4 & 0.713 & & & & & \\
\hline \multirow[t]{3}{*}{ Evaluation } & c9 & & 0.620 & & & & \\
\hline & c11 & & 0.690 & & & & \\
\hline & c12 & & 0.581 & & & & \\
\hline \multirow[t]{3}{*}{ Processing } & c16 & & & & & 0.619 & \\
\hline & $\mathrm{c} 17$ & & & & & 0.756 & \\
\hline & c18 & & & & & 0.608 & \\
\hline \multirow{7}{*}{$\begin{array}{l}\text { Communication/ } \\
\text { Diffusion }\end{array}$} & c20 & & & 0.775 & & & \\
\hline & $\mathrm{c} 21$ & & & 0.748 & & & \\
\hline & c22 & & & & 0.567 & & \\
\hline & c23 & & & & $\begin{array}{l}0.691 \\
0600\end{array}$ & & \\
\hline & $\begin{array}{l}\text { c24 } \\
\text { c25 }\end{array}$ & & & 0.641 & 0.600 & & $\begin{array}{r}\text { Table A2. } \\
\text { Factor model for BI in }\end{array}$ \\
\hline & $\begin{array}{l}c 26 \\
\% \\
\text { Explained }\end{array}$ & $36.37 \%$ & $7.16 \%$ & $\begin{array}{l}0.642 \\
6.74 \%\end{array}$ & $5.72 \%$ & $4.15 \%$ & $\begin{array}{l}\text { Spain. To facilitate } \\
\text { interpretation, only the } \\
\text { variables with a factor }\end{array}$ \\
\hline & $\begin{array}{l}\text { Variance } \\
\% \\
\text { cumulative }\end{array}$ & $36.37 \%$ & $43.53 \%$ & $50.26 \%$ & $55.98 \%$ & $60.14 \%$ & $\begin{array}{r}\text { loading higher than } 0.5 \\
\text { are included in the } \\
\text { models }\end{array}$ \\
\hline
\end{tabular}




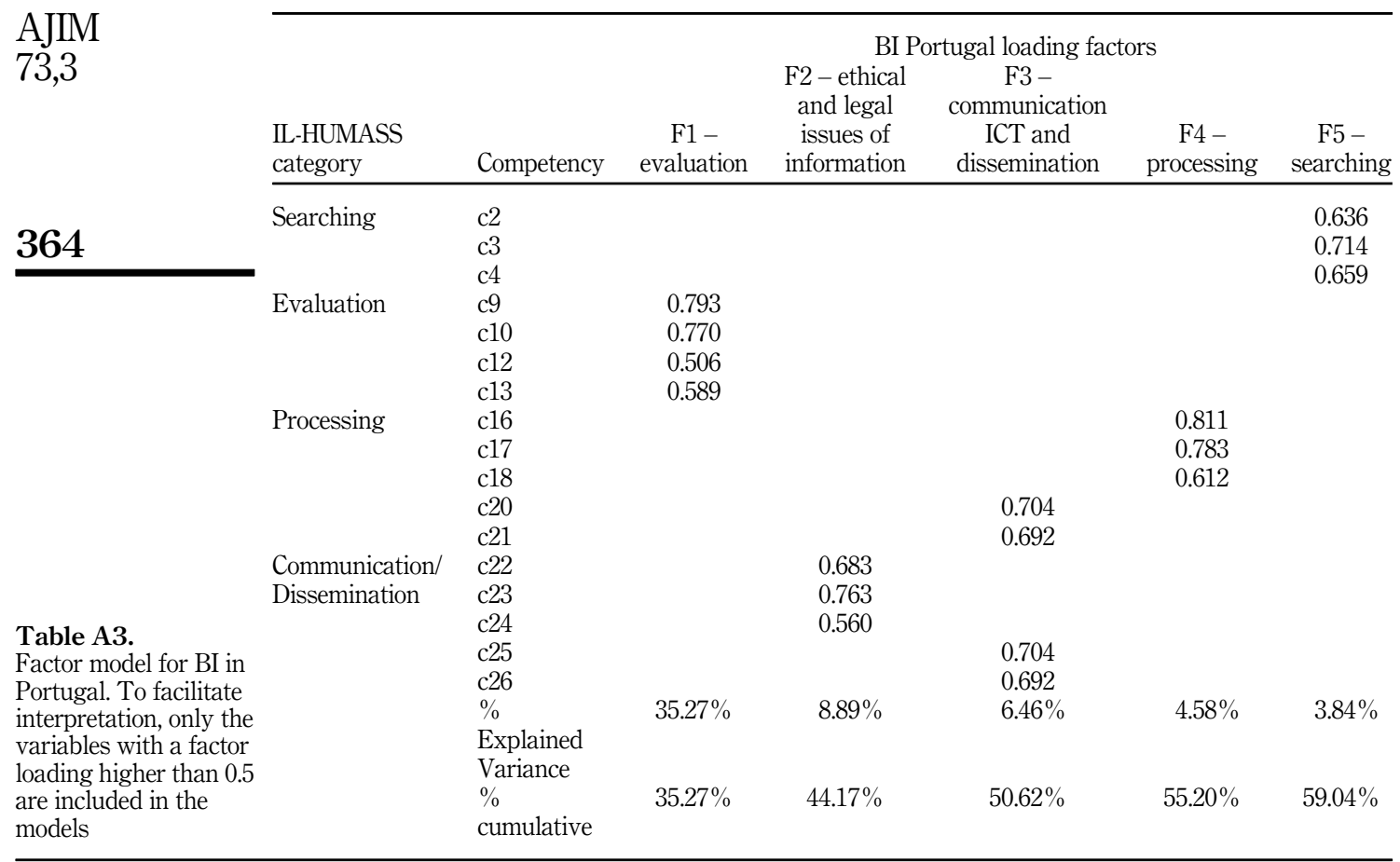




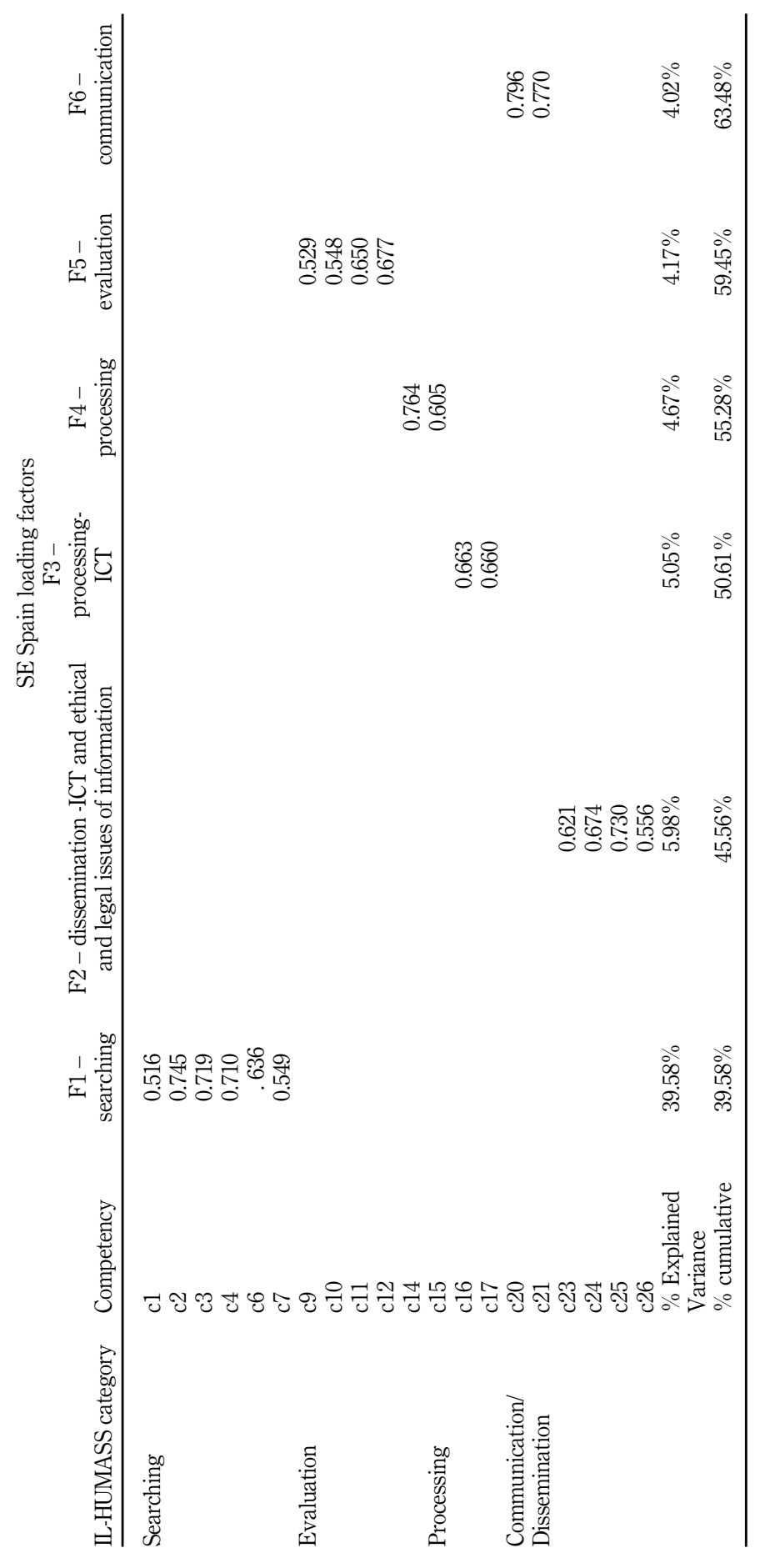

Perceptions of information literacy competencies

365

Table A4

Factor model for SE in

Spain. To facilitate interpretation, only the variables with a factor loading higher than 0.5 are included in the models 


\section{AJIM \\ 73,3}

366

Table A5.

Factor model for SE in Portugal. To facilitate interpretation, only the variables with a factor loading higher than 0.5 are included in the models

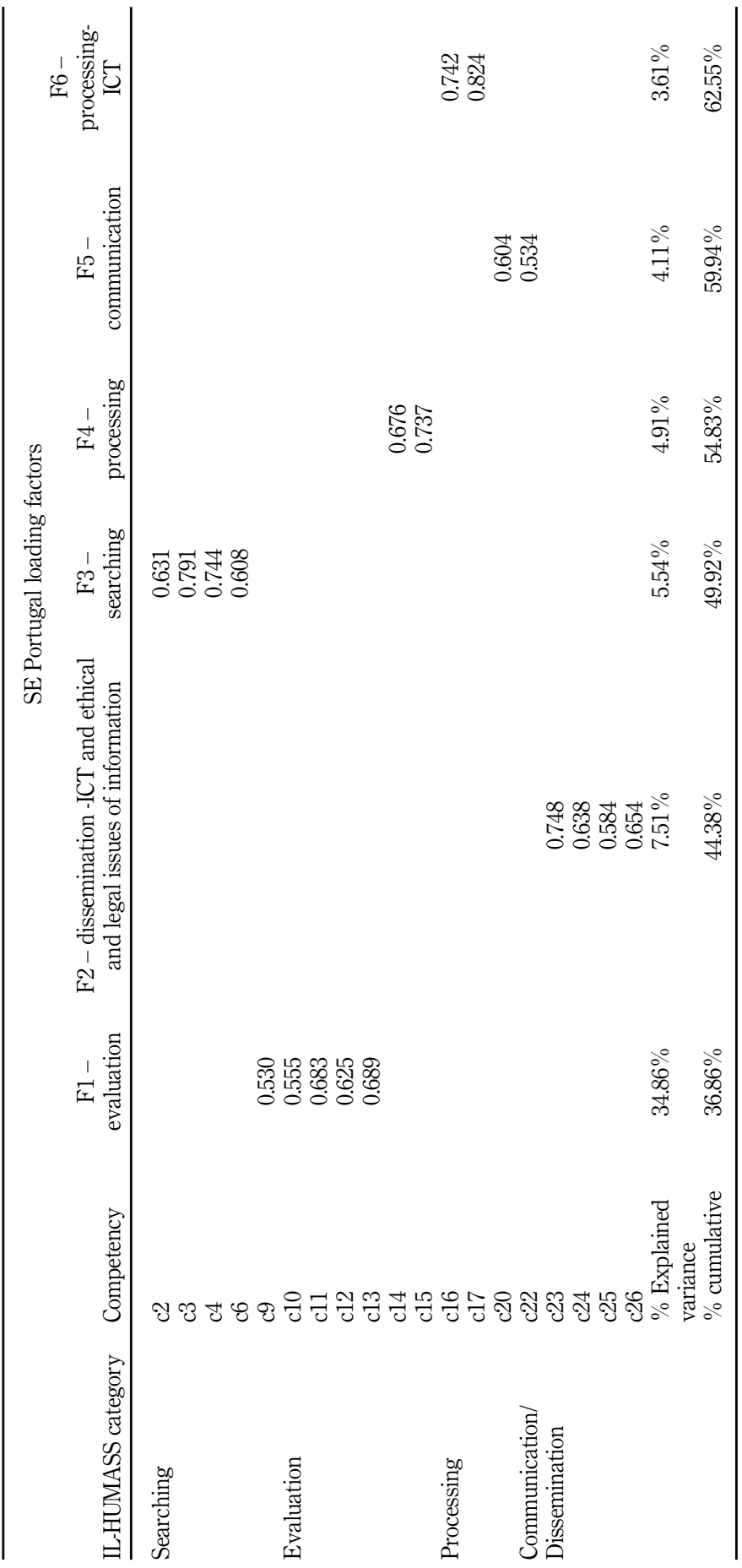

